\title{
Can Pedagogical Considerations Overcome Political Constraints? Principals' Perceptions of Leading in a Divided Community
}

\author{
Adam E. Nir \\ The Hebrew University of Jerusalem \\ adam.nir@mail.huji.ac.il
}

\begin{abstract}
The current study focuses on the implications that followed the construction of a Wall separating East and West Jerusalem for Arab school leaders leading schools located in East Jerusalem. Specifically, it focuses on the following question: can pedagogical considerations overcome political constraints? The study is based on an analysis of nineteen in-depth interviews conducted with thirteen male and six female public school principals leading East Jerusalem schools. Interviews reveal that the daily reality of East Jerusalem school leaders is made of constraints and opposing demands, forcing them to constantly struggle with immense role conflicts. Three main themes reflect the implications which followed the construction of the Wall for pedagogical and managerial considerations and conduct: restricted control, deception, and the national identity enigma. The dependency-separation blend characterizing the daily reality of Arab school leaders in East Jerusalem creates forces that are beyond their control and influence. It appears that school leaders' abilities to survive these limitations and obstacles mainly depends on their political skills and capabilities to maneuver among conflicting demands. Pedagogical knowledge and professional considerations come second.
\end{abstract}

\section{Introduction}

Public schools must interact with their environments. While their boundaries are formally defined, they are permeable and subject to external influences (DiPaola \& Tschennen-Moran, 2005). Since environmental opportunities and threats influence the strategies and professional conduct of organizational members (Weick, 1995), school leaders have long recognized that the interaction between a school and its environment is equally significant to the internal organizational processes for school effectiveness. Research, which followed this recognition, identified two adaptive strategies that school leaders typically employ when coping with their organizational environments. One line of research advocates for the vital role school leaders play in buffering external influences and pressures on schools (Cemaloğlu, 2011; Khademfar \& Idris, 2012; Korkmaz, 2004; 2007) so that teachers will not be distracted from their work (Dukem, 2004). A second line of research advocates for school leaders' needs to employ bridging strategies in order to attain resources and promote the interdependence of the organization with elements of its environment (DiPaola \& Tschennen-Moran, 2005).

Since public education is a segment within the political system, political considerations dominate public schools' environments, leading to educational policies that are based on contemporary political thought and interests (Popkewitz, 2000). Political interests determine educational financing and objectives, the national curriculum, the management of teachers, and evaluation standards (World Bank, 2004). Eventually, 
public schools are subject to various regulations, which follow political ideologies and agendas (Blanco \& Grier, 2009) that school leaders cannot ignore.

While political considerations are dominant in any national education context, their weight escalates in divided cities characterized by opposing cultures and political conflict. An ethno-political conflict creates unique complexities and tensions that have a direct influence over interpersonal relations, social identity, and the educational system (McGlynn et al., 2004). When running their schools, school leaders need to cope with this geopolitical reality and the obstacles it creates, which may undermine their professional judgment, considerations, and degrees of freedom. Complexity is likely to increase when schools located in a divided city operate in occupied territories and are subjected to the political culture, values, and regulations of the government in power.

Hence, the current study attempts to assess which adaptive strategies leaders of schools located in occupied territories employ and to what extent they are able to overcome political constraints set by the government in power and manage their schools based on professional considerations.

\section{Literature Review}

Schools are places inclined to be disorderly, complex, chaotic, and unpredictable. Such are the circumstances that school leaders face on a daily basis (Clarke \& Wildy, 2010). As a result, school leaders' work has always been considered stressful and demanding (Bush \& Jackson, 2002; Clarke, 2006; Creighton, 2005, p. 77; Dinham, 2011, p. 4; Huber, 2004; Møller, 2012; Ramsey, 2006; Sorenson, 2006). They need to cope with complexity (Zepeda, Parylo, \& Bengtson, 2014) following the vast spectrum of challenges and responsibilities created by the changing nature of student learners, the expansion of new technologies, the various demands presented by teachers and parents, and the turbulent educational environment in which schools operate (Nir, 2016). School leaders, thus, must be highly proficient jugglers when attempting to maneuver and successfully navigate among constraints and contradictory interests embedded in schools' internal and external context (Clarke \& Wildy, 2010). It is therefore not surprising that school leadership positions are difficult to maintain (Crow, 2006).

A school's socio-political context is considered among the main generators of the complexity school leaders experience on the job. It comprises a vast number of factors that have direct or indirect impact on schools (Bellamy, Fulmer, Murphy, \& Muth, 2003) and, therefore, on school leaders' abilities to act in accordance with their discretion, vision, and professional beliefs. Because public schools are funded by governments, political agendas have a direct impact on schools' resources, curricula, and values, as well as on student outcomes (Carnoy, Gove, \& Marshall, 2003). School leaders need, among their other role duties, to make sure their schools operate in accordance with the relevant legislation and policies. Leading schools effectively, consequently, relies heavily on school leaders' abilities to establish a delicate balance between school-level agendas and various demands coming from the school's socio-political context. The current study focuses on the implications that followed the construction of a Wall separating East and West Jerusalem for Arab school leaders leading schools located in East Jerusalem. 


\section{Divided cities}

Divided cities, which have become a worldwide phenomenon nowadays, create a unique socio-political context. In essence, a divided city is one that is comprised, as a consequence of political, ethnical, racial, ideological, or cultural dispute, of two separate entities. Polarization occurs when ethnic and nationalist claims combine and impinge significantly and consistently on distributional questions at the municipal level (Bollens, 1998). Examples of this phenomenon vary. Some cities that were divided in the past have become united, as in the case of Berlin. Other cities remain segregated, such as Belfast. Some cities are divided by physical barriers, such as Nicosia (Bollens, 2001) and Jerusalem (Choshen, 2005). Cities may also be divided without walls or physical barriers, as is the case in Johannesburg. Hence, the cities of the world may be arrayed along a continuum that begins with homogeneity and unity, moving through segregation and fragmentation, to division. A primary issue facing the government in a polarized city is how its ideology of urban governance will interact with the highly salient ethnonationalist ideologies of its competing populations (Bollens, 1998). Divided cities, hosting alternative and opposing cultures, witness violent political conflict and become sites where tensions are easily inflamed (Nasrallah, 2005). Needless to say, divided cities characterized by ethno-political conflict may create unique complexities for their residents, affecting their daily lives, social identities, their educational system, and interpersonal relations (McGlynn et al., 2004). These complexities are likely to be shared by educational leaders, who attempt to advance and educate children while operating under conflicting political, religious, ideological, and ethnic expectations.

\section{The unique case of the East Jerusalem educational system}

In 1967, Jerusalem was reunified as a result of the Six Day War, and the barriers that had separated the city's western and eastern sections were removed (Choshen, 2005). Israel extended its laws, jurisdiction, and administration to the occupied territories located in East Jerusalem and several nearby towns and villages, and it incorporated the area into the Jerusalem municipality. This arrangement lasted until September 2002. Following the second Palestinian uprising (Intifada), the Israeli government decided to renew the separation between East and West Jerusalem and began to construct a Wall as a means to stop the wave of violence produced by the uprising. The Wall disconnects eight Palestinian neighborhoods from the city, even though they are within Jerusalem's municipal boundaries and jurisdiction, and their residents are Palestinian Jerusalemites. Palestinians living in East Jerusalem are not considered citizens of Israel and they do not enjoy citizenship rights (Sa'ar, 2007). This split between residential and citizenship status may be evident in the fact that although East Jerusalem Palestinians pay taxes to the municipality, they politically ignore their local government as they do not participate in municipal elections. Instead, they choose to vote in the general Palestinian Authority elections, which have little influence over their daily lives (Cohen, 2007).

The Wall severely diminishes Palestinians' freedom of movement. It creates a growing dependency of the residents of East Jerusalem on the checkpoints for their livelihood, medical treatment, and family ties. Those residing in the area located between the Wall and the Green Line (the pre-1967 border) must obtain permits in order to enter the city's west side (Kaimari, 2005, p. 39). Moreover, the Wall became the most vivid and contemporary physical expression to the geopolitical circumstances and daily reality 
experienced by Palestinian Arabs who live in the occupied territories that Israel annexed during the 1967 war. The symbolic significance of the Wall is even more dramatic as it expresses the lack of resolution between Israel and Arab Palestinians.

While physical barriers may be found in various cities, the East Jerusalem educational system makes a unique case. Unlike other cities where a physical barrier creates total separation between educational systems operating on each side of the barrier (as in the case of Nicosia, where the northern part of the city is governed by the Turkish government and the south by the Greek), Arab schools located at East Jerusalem are governed by two opposing governments, which ignore each other (for a complete review, see Yair \& Alayan, 2009): the Israeli and the Palestinian Authority (PA). Legally, schools in East Jerusalem are under Israel's control (Klein, 2003; Safier, 2001), which is responsible for their funding and operation, the construction and maintenance of school buildings, the employment of superintendents, teachers and principals, and teacher preparation and certification. The PA is responsible for the curricula and the exams that students take at the end of twelfth grade - the Tawjihi (Al-Ramahi \& Davis, 2002). This split between Israel and the PA results in a bifurcated citizenship status for Palestinian residents of East Jerusalem, creating complexity and dilemmas for everyone involved with this educational system. The distinction between right and wrong for East Jerusalemites becomes a difficult and, at times, even an impossible task. This may especially hold true for educators who are constantly faced with the need to educate students and help them develop their own personal and national identities and moral sense. Arab school principals are caught in a double bind as a consequence of the different official agendas they are required to follow (Nir, 2011).

These circumstances create a highly delicate and complicated reality for Arab school leaders who need to cope with this geopolitical reality while attempting to run their schools. The fact that some of the children and teachers who live on the east side of the Wall have to go through checkpoints to reach their schools is one example to the daily complexity and uncertainty they face. What follows is a daily reality characterized by endless dilemmas requiring school leaders to tread precariously and maneuver between their inclinations to buffer and reject political pressures and demands, and their tendencies to cooperate using bridging strategies in order to attain resources likely to benefit their schools.

This study attempts to shed light on the unique challenges brought by the Wall for the leadership of Arab schools located in East Jerusalem. Specifically, it attempts to assess which adaptive strategies leaders of schools located in occupied territories employ and to what extent they are able to overcome political constraints set by the government in power and manage their schools based on professional considerations.

\section{Method}

\section{The context}

This study was conducted in Arab Muslim schools located in East Jerusalem. Estimated figures suggest the East Jerusalem school system is comprised of 88 public, 97 recognized and 79 private schools, indicating different levels of Ministry involvement and funding. Public schools accommodate about 45,000 students (Association for Civil 
Rights, 2017). In addition, according to a rough estimate provided by the municipality of Jerusalem, approximately 26,000 students study in private schools. As a result of the high birth rate, the school system in East Jerusalem grows by $6 \%$ each year, and the municipality fails to keep up with the growth by providing the needed infrastructure (Yair \& Alayan, 2009).

\section{Data collection}

The study is based on an analysis of nineteen in-depth interviews conducted with thirteen male and six female public school principals leading East Jerusalem schools. Interviews lasting from 60 to 90 minutes were conducted with twelve elementary, six junior high, and one high school principal. Interviews were chosen as the major data collection method to enable large amounts of data about interviewees' perspectives to be collected relatively quickly and the immediate follow-up and clarification of equivocal issues to be accomplished (Taylor \& Bogdan, 1984). To increase principals' willingness to collaborate with the study, all interviews were conducted by an Arabic-speaking Palestinian person.

In-depth open interviews were structured around a set of key issues that the literature identified as related to divided cities, with particular emphasis on the barriers to leading a school in a divided community. We used open-ended questions to enable better exposure of interviewees' personal perspectives, their deeper thoughts, emotions, and ambitions (Marshall \& Rossman, 2011; Patton, 2002; Rossman \& Rallis, 2012). This less structured approach allowed the interviews to be much more like conversations than formal events with predetermined response categories, permitting the respondents' views to unfold, rather than being influenced by the predisposition of the researcher (Merriam, 2009, p. 90). All interviews were recorded with the interviewees' permission to ensure better accuracy (Taylor, Bogdan \& DeVault, 2015). Later on, the recorded interviews were transcribed and translated onto computerized text files, which eventually formed the dataset.

\section{Data analysis}

The analysis of data involved classification of various issues to which the principals referred based on a set of identified central themes (Luborsky, 1994). Using the perspective of Marshall and Rossman (1997), who see qualitative data analysis "as a search for general statements among categories of data" (p. 111), and the procedures outlined by Marton (1988) and Forster (1994), comments were brought together on the basis of their similarities into categories that differed from one another in terms of the subject matter and meaning that each category represented. To enhance the validity of the data categorization and of the interpretations, the analysis of data was conducted by two independent researchers.

The data obtained from the interviews are analyzed and presented in two sequential phases. Initially, a description of the unique circumstances and professional challenges facing East Jerusalem school leaders is presented. Next, implications of the Wall for the daily administration of schools are discussed.

\section{Findings}


Any attempt to discuss the impact of the Wall separating East and West Jerusalem on the leadership and administration of schools must initially take into account the unique circumstances characterizing the daily reality of Arab schools operating in the occupied territories of East Jerusalem. While school leadership is generally considered a highly complicated task, complexity in East Jerusalem is aggravated following the variety of contradictory interests and political agendas that school leaders are expected to satisfy. A variety of examples are offered by school leaders when asked to refer to the influence of the unique geopolitical circumstances characterizing East Jerusalem on their role complexities.

One controversial issue involves annual school trips. According to the regulations set by the Israeli Ministry of Education, every school trip must be escorted by armed security guards. While this is a common practice for Israeli Jewish schools, Palestinian Arabs are not willing to comply with this demand. Thus, school leaders need to search for creative solutions when faced with these contradicting expectations: "Since parents object to armed security guards, I invite only one instead of three and ask him to conceal his weapon. This allows us to pay respect to the culture and customs of the people in our village" (Hatem). Samira offers a different solution to this dilemma:

I tried to explain to the parents that an armed guard is important for the safety of their children. I managed to convince some but not all of them. So, I invited guards who live in Arab villages in the north and are allowed to carry weapons.

Another typical dilemma involves Jewish holidays, such as Israel's Independence Day. According to the Israeli Ministry of Education, public schools, like any other national institution, should be closed on this day. However, for Arab Palestinians, this day signifies their defeat in the 1948 war which resulted in 700,000 Palestinian refugees.

I couldn't just send a letter to the parents saying that the school will be closed on Israel's Independence Day. So, I decided to issue a letter to the parents on the Jerusalem municipality letterhead. This way, it was the municipality and not me who decided to close the school on that day. (Ahed)

Ja'afar offers another creative solution: "I sent parents a letter saying that school will be closed on that day because, according to army and police orders, the roads will be closed and transportation will be impossible."

A third example of the unique complexities facing Arab school leaders in East Jerusalem may be found in the acquisition of books for the beginning of the school year. Books that are used in Arab schools in East Jerusalem must have the Jerusalem municipality logo on their covers and should be bought from the municipality. This regulation was set to ensure that books' content is approved by Israeli authorities. However, every year the municipality fails to prepare to books on time for the beginning of the school year. Says Salwa: 
We must buy the books from the municipality. However, the books are never ready on time and we are not allowed to buy books from the Palestinian Authority. So, parents collect money and buy the books for a cheaper price without the municipality's logo. This way, if someone comes and asks why the books don't have the municipality's logo, I can say that it is not the school but the parents who bought the books.

These examples suggest that principals use bridging and buffering strategies occasionally, while attempting to minimize potential conflicts.

The tendency of the Israeli authority to control the educational curriculum in East Jerusalem schools produces various restrictions that are evident not only in the list of approved books but also in the issues that schools may or may not include in their programs. One example to the limitation facing school leaders may be evident in the eighth grade geography curriculum. According to the regulations issued by the Israeli municipality and Ministry of Education, East Jerusalem schools are not allowed to use geography books published by the PA which refer to the territories annexed by Israel during the 1967 war as occupied territories. Yet, there are no alternative geography books written in Arabic for the eighth grade that are approved by the Israeli authorities.

It is not worth the risk [to teach geography using the forbidden book]. I am unwilling to break the law. Therefore, as far as I am concerned, it is wiser not to teach geography at all rather than become involved in a dispute with the Israeli authorities. (Najua)

Another example indicating the same difficulty involves citizenship studies:

We are not allowed to use the Palestinian book because it discusses the Palestinian state [which is not recognized by the State of Israel]. Some school principals who used this book were taken for interrogation by the Israeli security forces not a pleasant experience, as you might imagine. Therefore, we teach citizenship studies but don't use a book. (Ahed)

A fourth and final example to the complexities school leaders in East Jerusalem face may be found in the contradicting demands presented by the Israeli and the Palestinian authorities regarding the transparency of students' grades. According to Palestinian regulations, schools are not allowed to fail more than 5\% of the students in each academic year. Says Saeed: "Last year, there were many students who failed. However, because of Palestinians regulations, we decided not to fail them." Hatem further clarifies:

Last year I was summoned by the person in charge of the Arab schooling system in East Jerusalem at the Jerusalem municipality. She warned me not to fail students because, according to regulations, the municipality must provide schools with extra funding for every student who fails and the 
municipality is reluctant to do so. So, although it is against

my better judgment, we no longer fail students in our school.

Hence, the daily reality of East Jerusalem school leaders is made of constraints and opposing demands, forcing them to constantly struggle with immense role conflicts characterized by varying intensities. Doing the right thing when leading schools would be, in many cases, finding a course of action that would cause the least disagreement and stress, even if this mode of operation comes at the expense of professional considerations.

\section{The Wall}

The Wall separating East and West Jerusalem intensifies the tension and complexity shared by Jerusalemites as it emphasizes the discrepancies among the various political and ideological agendas and increases the friction between Israeli security forces and Palestinian inhabitants. Interviews conducted with East Jerusalem school leaders reveal three main themes indicating the limitations created by the Wall for pedagogical and managerial considerations and conduct.

\section{Restricted control}

Leadership is about setting a clear direction through the development and communication of shared goals that encourage a sense of common purpose and high performance expectations among followers (Ylimaki et al., 2012). The ability to control followers' behaviors is considered to be among leaders' essential capacities. However, when Arab school leaders in East Jerusalem refer to the impact of the Wall on their daily conduct, they all mention that it restricts their ability to control the behaviors of students and teachers in their school.

One of the most frequently mentioned examples regarding this limitation is related to students' and teachers' delays. The fact that many students live on the other side of the Wall and need to pass through checkpoints creates a limitation that school leaders cannot overcome. As Afaf describes, "Every day, the minibuses that bring children to school are late, mainly because of the checkpoints like the one in Kalandia (a neighborhood located on the Palestinian side of the Wall). I always ask the drivers to collect the kids earlier but this doesn't help much." Further, Saeed says,

Because of the Wall, some families are divided. When the children visit during the weekend their father who lives on the other side of the Wall, they will always come late to school the next day. This is a constant problem to which we don't have a solution.

Ali summarizes:

Every school day begins with less than half of our students. The rest come one hour later or don't come at all. When I call the minibus company, their permanent excuse is that the checkpoint was closed and they were not allowed to go through. Then, I receive phone calls from parents claiming that the people in the 
minibus company are lying and that there is no problem at the checkpoints. This puts me in an awkward situation: whom should I believe? Sometimes, I don't have a choice but to drive to the checkpoint and see with my own eyes whether it is open or closed. This is a very tough reality but as a school principal there is nothing that I can do about it.

The circumstances in Jerusalem and therefore also at the checkpoints are fragile, dynamic, and unpredictable, and they may change rapidly. This understanding encourages some of the students who live on the Palestinian side of the Wall to leave their homes early morning and reach school long before it opens. As a result, students sit and wait near the school entrance without the supervision of school staff members.

Some of the students come to school very early, even before 07:00 am, and I cannot be responsible for their safety when they sit outside the school gate and wait. (Samira)

Some of the students who come early are 6 or 7 years old. When they wait near the school gate they are not safe. I cannot force the teachers to come to school an hour before the school officially opens. I feel frustrated that I cannot ensure the safety of these kids. (Nidal)

To avoid the heavy traffic at the checkpoint, minibuses pick up our students early in the morning and drop them at school at 06:30. Many times kids get into trouble when waiting in the street. I applied to the municipality officials and asked them to talk with the managers of the minibus company, but they were reluctant to become involved in this matter. I don't have any influence on the minibus company. (Mustafa)

School leaders' difficulty in dealing with delays is also evident when teachers' delays are concerned. According to Saeed:

Teachers living on the Palestinian side of the Wall are usually late. This creates many difficulties which I try to avoid by placing their lessons at 09:00 instead of 08:00 am. I always ask them to leave their homes earlier although this doesn't help much. In some cases, they leave home at 06:00 and reach school by 09:00. The Wall creates a huge dilemma which I cannot solve since it is totally in the hands of the Israeli security forces.

Ja'afar further elaborates:

Although I ask my teachers to come to school earlier, I realize that they are also mothers who need to take their own kids to kindergartens and schools which are not open before 07:15. In some cases, teachers who have to be on duty in the early 
morning fail to arrive on time. This is a very complicated issue creating a lot of stress and pressure on my job as I have limited capacity to control my staff.

An immediate result of school leaders' limited abilities to eliminate students' and teachers' delays may be evident in their difficulties planing their schools' working days.

I can never plan my day before it actually begins. First I come to school, get a better idea of the problems that I need to solve on that particular day and, only then, I begin to think how to proceed. (Ali)

I start every day dealing with various problems which follow the delays of kids and teachers because of the Wall. I cannot create a weekly plan for school because of the many uncertainties and unexpected occurrences. (Ja'afar)

The inability to produce a weekly plan and follow it undermines school principals' ability to effectively deal with pedagogical issues:

Because of the Wall and the many daily problems it creates, I hardly find the time to deal with core issues such as teaching materials or the construction of educational programs. (Samira)

In addition to the daily uncertainties the Wall creates, it also has a direct effect on classrooms' crowdedness and, therefore, on school leaders' abilities to control their schools' internal processes. Following the construction of the Wall, many families decided to rent apartments on the western side of the Wall. While the number of students in each school has increased significantly, school buildings, courtyards, and classrooms have remained the same and are not big enough to absorb all students. Ahed describes these newly created circumstances:

Before the Wall was constructed, 212 students studied in our school. Today we have 340 students. All the families that lived on the east side of the Wall came back to the neighborhood and registered their children to our school. We must accept these children because in our neighborhood there are only two schools: ours and another one which contains over 1,300 students. Although our classes are able to contain 20 students, in practice, 40 students study in each classroom. Our teachers find it very hard to teach meaningful lessons.

The extreme crowdedness requires school principals to search for creative solutions, although their control of the processes taking place in their schools is limited. Says Nidal:

Our school building is not big enough. There are no nearby buildings that we can rent. So, our school operates in two shifts: the elementary school begins at 08:00 am and the junior high 
school begins later and continues until 16:00 pm. Our students don't study the entire curriculum because we cannot provide enough classrooms.

Restricted control creates various constraints and limitations that are beyond school leaders' managerial capacities. Hence, they improvise and act in ways likely to reduce potential frictions and disputes.

\section{Deception}

The construction of the Wall and the separation it creates between east and west has a significant impact on the legal status and civil rights of residents living on each side. In essence, those living on the east side must get permits in order to cross to the other side of the Wall and do not enjoy the services granted by the Jerusalem municipality to residents living on the west side. So, many families have two addresses, one on each side of the Wall. However, this creates several legal difficulties for school leaders, requiring them to tread precariously and, in some cases, act dishonestly in order to avoid confrontations. As Najua describes,

In order to obtain welfare services provided by the municipality, all parents who have two addresses declare they live on the west side of the Wall. However, after the school year begins, I discover that they actually live on the east side. Transportation services are provided by the municipality only to students living on the east side of the Wall. However, parents are unwilling to tell the truth regarding their actual place of residence because this might negatively affect their welfare rights. So, they expect me to collaborate with them and conceal from the municipality the facts regarding their actual place of residence.

The need to lie when reporting students' actual places of residence serves schools' interests, especially when the Social Welfare services provided by the Jerusalem municipality are required.

Parents must meet two conditions if they wish to receive welfare services: they must have a blue (Israeli) identity card and they must live on the west side of the Wall. Some of our students live on the east of the Wall and although the parents have blue identity cards they are not entitled to obtain welfare services. For example, when a student living on the east side has special needs, I cannot use the services of the municipality's Diagnostic Committee in order to determine what specific services he/she should be getting. So, when asked, I say that this student lives on the west side of the Wall although I know that this is not the case. I do so because my main obligation is to my students. However, this put me in a difficult position towards the parents because now their child loses the right to receive transportation services. (Ja'afar) 
I find myself in constant conflict. I hate to be dishonest, but because of the reality created by the Wall, I don't have much choice. If I tell the truth I get in trouble with the parents, and if I collaborate with the parents I might get in trouble with the municipality and the Ministry of Education - my employer. (Samira)

The fact that families keep two apartments on both sides of the Wall creates complex and delicate situations requiring school principals to act deceitfully. This is the case when teenage girl students live by themselves in rented apartments on the west side of the Wall while their families live on the east side.

Many families allow girls who are teenagers to stay by themselves in a rented apartment. Unfortunately, these girls take advantage of these circumstances and invite over their male friends. In such cases, I immediately report to the Welfare Department at the municipality. As for the parents - I can't tell them the truth because if they would know that their daughters have relationships with boys, they might murder them. So, I hide this information while trying to persuade the parents that they shouldn't allow their daughters to live by themselves. (Najua)

School leaders choose deception as their coping strategy in order to provide students more resources and better educational services while avoiding conflict with parents. For this purpose, they adopt a pragmatic mode of operation evident in their tendency to employ both bridging and buffering strategies even if such conduct comes at the expense of their own values and professional considerations.

\section{The national identity enigma}

As a physical barrier, the Wall emphasizes ideological and political differences, and the separation between the Arab and Jewish citizens of Jerusalem. While Jewish students are called to engage in the collective Jewish national enterprise, Palestinian students are called on to accept the definition of Israel as a Jewish Democratic state (Al-Haj, 2002) and are not allowed to choose freely their own narratives concerning issues related to their cultural and national histories and identity (Bekerman \& Nir, 2006).

The fact that Arab schools located on the west side of the Wall are governed by both the Israeli and the Palestinian authorities that oppose and ignore each other frequently puts school principals in awkward and complicated situations. While complexity characterizes almost every aspect of schools' daily routines, dealing with students' ideological and national identities may be viewed as one of school leaders' most challenging role assignments. As educational leaders, they are expected to assist their students to develop their ideological and national identities, yet, in the unique circumstances in which they operate, discussing these issues seems equivalent to a walk in a minefield.

When referring to the impact the Wall has on their tendency to initiate educational processes aimed towards developing their students' ideological and national identity, 
most principals express fear to deal with this issue. Hatem explains: "Politics and religion are delicate issues and you better avoid discussing these issues in school if you don't want to get in trouble with the parents and other community members." Saeed provides a vivid example, which emphasizes his fear and difficulty dealing with identityrelated issues:

One of the teachers composed a song about peace with lyrics in Hebrew, Arabic and English and the students sang it in one of the school parties. When the event was over, a few parents complained, arguing that songs about peace that are sung in Hebrew are not suitable for Muslim Arabs who live in the divided city of Jerusalem. I had to deal with these parents for the entire day to persuade them that the song was suitable.

Salwa summarizes:

We don't directly discuss issues related to our students' national identity. We tell them that they are Arab Palestinians but nothing more. The teachers are afraid to discuss this issue and are not willing to discuss it with the students.

The fear of becoming involved in educational discussions focusing on the national identities of the students encourages teachers and school principals to search for ways to enable the discussion of this issue indirectly. Discussing universal values is one way to do this, as Najua explains:

In our school we don't go deep while discussing issues related to students' national identity. It is important for us to emphasize issues such as contribution to the community, leadership, the importance of a future perspective with particular emphasis on higher education and the development of a professional career. We focus on universal values as we don't want to get into trouble. We place our emphasis on general values and avoid the particular complexities characterizing the daily life of Arab Palestinians in Jerusalem.

However, most school leaders prefer to avoid any discussions in their schools that focus on the national identities of their students. Although they consider this issue very important, they also view it highly explosive. Therefore, they tend to use avoidance as their main strategy when issues related to students' national identities are mentioned:

I believe that most school principals tend not to discuss the national identity issue because they don't have the tools which allow dealing with the complexities involved. Can the Arab citizens in Jerusalem actually define their national identity? I doubt it. (Najua) 
In considering the new circumstances created following the second Palestinian uprising (Intifada) and the construction of the Wall, I don't think the teachers are able to deal with this complicated issue. I am sure the parents would also object to that. Hence, currently it is better to avoid this issue and hope for a better future. (Nidal)

I really don't know how to deal with this issue. The teachers are afraid to talk about national identity because they are afraid to get into trouble with the Israeli authorities. Thus, students' national identity is formed through students' daily experiences, Muslim holydays and various events taking place in the city. School is hardly involved in this process. (Hatem)

In light of the manifested policy of the Israeli municipality and Ministry of Education, any discussion concerning the national identity of Arab students who study in schools located in the occupied territories is obviously highly delicate and dangerous. Hence, school leaders tend to use both buffering and avoidance as their coping strategies in order to evade confrontations with both Israeli officials and members of their schools' local communities.

\section{Discussion}

Institutional theory posits that organizations tend over time to become isomorphic with their environments (DiMaggio \& Powell, 1983; Meyer \& Rowan, 1977; Scott, 1987). In this sense, Arab schools in East Jerusalem may be viewed as microcosms reflecting the tragedy that grew out of the political and ideological conflict between Arabs and Jews living in a divided city. While the construction of the Wall intensified the split and separation between the two national groups, it also maintained and even increased the dependency of Arab schools on the Israeli-Jewish establishment.

This dependency-separation blend creates a unique challenge for Arab school leaders in terms of their degrees of freedom and abilities to introduce and maintain an educational agenda based on their professional beliefs and considerations. These circumstances promote the dominance of political limitations over educational considerations and increase the perceived risk and uncertainty that Arab school leaders experience on the job. Previous studies have shown that passiveness is often s manager's typical reaction to unstable and risky circumstances as a means to buffer the risk (Bedell, Hunter, \& Mumford, 2008; Collins, 2001; Ensley, Pearce, \& Hmieleski, 2006; Hunter, BedellAvers, \& Mumford, 2009; Janis \& Mann, 1980; Nir \& Eyal, 2003). My findings indicate that the Wall creates an insurmountable obstacle, which limits school leaders' abilities to initiate, plan, act proactivel,y or fully control the educational activities taking place in their schools. School leaders, teachers, students, and parents, as well as educational agendas and pedagogical considerations, become the victims of this highly volatile political reality. School leaders are often exposed to changing and unpredictable occurrences that they cannot ignore or contain, requiring them to make changes and adjust the activities and educational processes they had intended to initiate. These circumstances promote hybrid conflicts (Nir, 2011), exposing school leaders to lose-lose 
situations in terms of their abilities to make decisions that would potentially ease their stresses, while allowing them to initiate and implement educational processes in line with their professional discretion. Hybrid conflicts push educational leaders to the edge, while impelling them to adopt a distorted professional agenda. In this sense, hybrid conflicts shift the focus from the ethical to the practical arena, inducing school leaders to adopt a cost-benefit minimal risk strategy. According to Arab school leaders, these circumstances seem to promote the legitimacy of deception as a means for diminishing potential conflicts and confrontations. However, in the long run, this mode of operation is likely to increase leaders' burnout, undermine their professional judgment, and eventually damage the quality of educational services their schools provide to students.

\section{Conclusion}

Leading Arab schools located in divided and occupied territories governed by an Israeli authority creates geopolitical complexities, which go much beyond educational and professional considerations. Although educational leaders may employ various strategies in order to adapt to their environments (DiPaola \& Tschennen-Moran, 2005), it appears that under chaotic and extreme circumstances school leaders are unable to stick to a single strategy. Rather, they must juggle among coping strategies if they wish to stay on the job and allow their schools to get the most benefit. This conclusion is in line with Ogawa's (1996) argument stating that schools employ both buffering and bridging strategies as they interface with their environments.

Arab school leaders in Jerusalem, consequently, face forces beyond their control and influence. While lack of resources or limited pedagogical freedom characterizing their daily experience may cause them frustration, failing to meet the various political demands and expectations may be risky and dangerous for them and their schools. It appears, for this reason, that school leaders' abilities to survive these limitations and obstacles mainly depends on their political skills and abilities to maneuver among conflicting demands and coping strategies. Pedagogical knowledge and professional considerations come second.

\section{References}

Al-Haj, M. (2002). Multiculturalism in deeply divided societies: The Israeli case. International Journal of Intercultural Relations 26(2), 169-183. https://doi.org/10.1016/S0147-1767(01)00048-7

Al-Ramahi, N., \& Davis, B. (2002). Changing primary education in Palestine: Pulling in several directions. International Studies in Sociology of Education, 12(1), 59-76. https://doi.org/10.1080/09620210200200083

Association for Civil Rights. (2017). The response of the Jerusalem Municipality to a request based on the freedom of information act, 29 March, 2017 (Hebrew). Bedell, K. E., Hunter, S. T., \& Mumford, M. D. (2008). Conditions of problemsolving and the performance of charismatic, ideological and pragmatic leaders: A comparative experimental study. The Leadership Quarterly, 19(1), 89-106. https://doi.org/10.1016/j.leaqua.2007.12.006

Bekerman, Z., \& Nir, A. E. (2006). Opportunities and challenges of integrated education in conflict ridden societies: The case of Palestinian-Jewish schools 
in Israel. Childhood Education, 82(6), 327-333.

https://doi.org/10.1080/00094056.2006.10522857

Bellamy, G. T., Fulmer, C., Murphy, M., \& Muth, R. (2003). A framework for school leadership accomplishments: Perspectives on knowledge, practice, and preparation for principals. Leadership and Policy in Schools, 2(4), 241-261. https://doi.org/10.1076/lpos.2.4.241.17892

Blanco, L., \& Grier, R. (2009). Long life democracy: The determinants of political instability in Latin America. Journal of Development Studies, 45(1), 76-95.

Bollens, S.A. (1998). Urban planning amidst ethnic conflict: Jerusalem and Johannesburg. Urban Studies, 35(4), 729-750. https://doi.org/10.1080\%2F0042098984727

Bollens, S. (2004). Urban Planning and Intergroup Conflict: Confronting a Fractured Public Interest. In B. Stiftel \& V. Watson (Eds.), Dialogues in Urban and Regional Planning (pp. 209-46). Routledge.

Bollens, S. A. (2001). City and Soul: Sarajevo, Johannesburg, Jerusalem, Nicosia. City, 5(2), 169-87.

Bush, T., \& Jackson, D. (2002). A preparation for school leadership: International perspectives. Educational Management and Administration, 30(4), 417-429. https://doi.org/10.1177\%2F0263211X020304004

Carnoy, M., Gove, A., \& Marshall, J.H. (2003). Why do students achieve more in some countries than others? A comparative study of Brazil, Chile, and Cuba. Stanford University, School of Education.

Cemaloğlu, N. (2011). Primary principals' leadership styles, school organizational health and workplace bullying. Journal of Educational Administration, 49(5), 495-512. https://doi.org/10.1108/09578231111159511

Choshen, M. (2005). Demographic processes in polarized cities: The case of Jerusalem. In M. Auga, S. Hasson, R. Nasrallah, \& S. Stetter (Eds.), Divided cities in transition: Challenges facing Jerusalem and Berlin (pp. 3-34). The Friedrich Ebert Stiftung, The International Peace and Cooperation Center and The Jerusalem Institute for Israel Studies.

Clarke, S. (2006). From fragmentation to convergence: Shaping an Australian agenda for quality school leadership. School Leadership and Management, 26(2), 169182. https://doi.org/10.1080/13634230600589725

Clarke, S., \& Wildy, H. (2010). Preparing for principalship from the crucible of experience: Reflecting on theory, practice and research. Journal of Educational Administration and History, 42(1), 1-16. https://doi.org/10.1080/00220620903462116

Cohen, H. (2007). The rise and fall of Arab Jerusalem, 1967-2007. Jerusalem Institute for Israel Studies.

Collins, J. C. (2001). Good to great: Why some companies make the leap and others don't. Harper Business.

Creighton, T. (2005). Leading from below the surface: A non-traditional approach to school leadership. Corwin Press.

Crow, G. M. (2006). Complexity and the beginning principal in the United States: Perspectives on socialization. Journal of Educational Administration, 44(4), 310-325. https://doi.org/10.1108/09578230610674930 
DiMaggio, P. J., \& Powell, W. W. (1983). The iron cage revisited: Institutional isomorphism and collective rationality in organizational fields. American Sociological Review, 48(2), 147-160. www.jstor.org/stable/2095101

Dinham, S. (2011). Pilot study to test the exposure draft of the national professional standard for principals. Australian Institute for Teaching and School Leadership.

https://www.researchgate.net/profile/Stephen_Dinham2/publication/265524937_Pi lot_study to test the exposure_draft_of the National_Professional_Standard_for _Principals/links/5592619508ae47a34910e7fa/Pilot-study-to-test-the-exposuredraft-of-the-National-Professional-Standard-for-Principals.pdf

DiPaola, M. F., \& Tschennen-Moran, M. (2005). Bridging or buffering? The impact of schools' adaptive strategies on student achievement. Journal of Educational Administration, 43(1), 60-71. https://doi.org/10.1108/09578230510577290

Dukem, D. (2004). Turnaround principal: High-stakes leadership. Principal, 84(1), 13-23.

Ensley, M. D., Pearce, C. L., \& Hmieleski, K. M. (2006). The moderating effect of environmental dynamism on the relationship between entrepreneur leadership behavior and new venture performance. Journal of Business Venturing, 21(2), 243-263. https://doi.org/10.1016/j.jbusvent.2005.04.006

Forster, N. (1994). The analysis of company documentation. In C. Cassel \& G. Symon (Eds.), Qualitative methods in organization research (pp. 148-160). Sage.

Huber, S. H. (2004). School leadership and leadership development: Adjusting leadership theories and development programs to values and the core purpose of school. Journal of Educational Administration, 42(6), 669-684. https://doi.org/10.1108/09578230410563665

Hunter, S. T., Bedell-Avers, K. E., \& Mumford, M. D. (2009). Impact of situational framing and complexity on charismatic, ideological and pragmatic leaders: Investigation using a computer simulation. The Leadership Quarterly, 20(6), 383-404. https://doi.org/10.1016/j.leaqua.2009.03.007

Janis, I. L., \& Mann, L. (1980). Decision making. Free Press.

Kaimari, M. (2005). Understanding the socio-cultural facts created by planning East Jerusalem. In M. Auga, S. Hasson, R. Nasrallah, \& S. Stetter (Eds.), Divided cities in transition: Challenges facing Jerusalem and Berlin (pp. 35-52). The Friedrich Ebert Stiftung, The International Peace Cooperation Center and The Jerusalem Institute for Israel Studies.

Khademfar, M., \& Idris, K. (2012). The relationship between transformational leadership and organizational health in Golestan Province of Iran. International Journal of Humanities and Social Science, 2(12), 218-230.

Klein, M. 2003. The Jerusalem problem: The struggle for permanent status. University Press of Florida, Jerusalem Institute for Israel Studies.

Korkmaz, M. (2004). The relationship between organizational health and robust school vision in elementary school. Journal of Educational Planning and Administration, 18(4), 437-488.

Korkmaz, M. (2007). The effects of leadership styles on organizational health. Educational Research Quarterly, 30(3), 22-54.

Luborsky, M. R. (1994). The identification and analysis of themes and patterns. In J.F. Gubium \& A. Smakar (Eds.), Qualitative methods in aging research (pp. 189-210). Sage. 
Merriam, S. B. (2009). Qualitative research: A guide to design and implementation. Jossey-Bass.

Marshall, C., \& Rossman, G. (1997). Designing qualitative research ( $2^{\text {nd }}$ ed.). Sage.

Marton, F. (1988). Phenomenology: A research approach to investigate different understandings of reality. In R.R. Sherman \& R.B. Webb (Eds.), Qualitative research in education: Focus and methods (pp. 143-161). Falmer Press.

McGlynn, C., Niens, U., Cairns, E., \& Hewstone, M. (2004). Moving out of conflict: The contribution of integrated schools in Northern Ireland to identity, attitudes, forgiveness and reconciliation. Journal of Peace Education, 1(2), 147-161. https://doi.org/10.1080/1740020042000253712

Meyer, J. W., \& Rowan, B. (1977). Institutionalized organizations: Formal structure as myth and ceremony. American Journal of Sociology, 83(2), 340-363. https://doi.org/10.1086/226550

Møller, J. (2012). The construction of a public face as a school principal. International Journal of Educational Management, 26(5), 452-460. https://doi.org/10.1108/09513541211240246

Nasrallah, R. (2005). Transformations in Jerusalem: Where we are heading? In M. Auga, S. Hasson, R. Nasrallah, \& S. Stetter (Eds.), Divided cities in transition: Challenges facing Jerusalem and Berlin (pp. 205-225). The Friedrich Ebert Stiftung, The International Peace Cooperation Center and The Jerusalem Institute for Israel Studies.

Nir, A. E. (2016). Educational planning: The ethics of compromise. Educational Planning, 23(1), 5-17. http://isep.info/wp-content/uploads/2016/04/231_1TheEthicsofCompromise.pdf

Nir, A. E. (2011). The emergence of hybrid role conflict in conflicting settings: A unique challenge for school leaders. International Journal of Educational Reform, 20(4), 343-360. https://doi.org/10.1177\%2F105678791102000404

Nir, A. E., \& Eyal, O. (2003). School-based management and the role conflict of the school superintendent. Journal of Educational Administration, 41(5), 547-564. https://doi.org/10.1108/09578230310489362

Ogawa, R. I. (1996). Bridging and buffering relations between parents and schools. University Council of Educational Administration (UCEA) Review, 37(2), 2$3,12-13$.

Patton, M.Q. (2002). Qualitative research and evaluation methods (3rd ed.). Sage.

Popkewitz, T. S. (2000). Educational knowledge: Changing relationship between the state, civil society, and the educational community. State University Press.

Ramsey, R. D. (2006). Lead, follow, or get out of the way: How to be a more effective leader in today's schools (2nd ed.). Corwin Press.

Rossman, G. B., \& Rallis, S.F. (2012). Learning in the field: An introduction to qualitative research (3rd ed.). Sage.

Sa'ar, A. (2007). Contradictory location: Assessing the position of Palestinian women citizens of Israel. Journal of Middle East Women's Studies, 3(3). 45-74. https://doi.org/10.1215/15525864-2007-4003

Safier, M. (2001). The Jerusalemite question. Palestine-Israel Journal of Politics Economics and Culture, 8(3), 47-63. https://search.proquest.com/docview/235667419?accountid=14546

Scott, W. R. 1987. Organizations: Rational, natural, and open systems (2nd ed.). Prentice-Hall. 
Sorenson, R. (2006). Helping new principals succeed. American School Board Journal, 192(4), 61-63.

http://eds.a.ebscohost.com/eds/pdfviewer/pdfviewer?vid=1\&sid=57c386d5-1aa740ad-8aad-2637311cea0f\%40sessionmgr4007

Taylor, S. J., \& Bogdan, R. (1984). Introduction to qualitative research methods: The search for meaning. Wiley.

Taylor, S. J., Bogdan, R., \& DeVault, M. (2015). Introduction to qualitative research methods: A guidebook and resource. John Wiley \& Sons.

Weick, K. E. (1995). Sensemaking in organizations. Sage.

World Bank. (2004). World Development Report, 2004: Making services work for poor people. World Bank and Oxford University Press.

Yair, G., \& Alayan, S. (2009). Paralysis at the top of a roaring volcano: Israel and the schooling of the Palestinians in East Jerusalem. Comparative Education Review, 53(2), 235-257. https://doi.org/10.1086/598168

Ylimaki, R. M., Bennett, J. V., Fan, J., \& Villasenor, E. (2012). Notions of 'success' in Southern Arizona schools: Principal leadership in changing demographic and border contexts. Leadership and Policy in Schools, 11(2), 168-193. https://doi.org/10.1080/15700763.2011.585539

Zepeda, S. J., Parylo, O., \& Bengtson, E. (2014). Analyzing principal professional development practices through the lens of adult learning theory. Professional Development in Education, 40(2), 295-315.

https://doi.org/10.1080/19415257.2013.821667 